\title{
Laïcité and Laiklik: When Did the Comparability of Assertive Laicism in France and Turkey Dissolve?
}

\author{
Julia Jakus ${ }^{1,2,3}$ \\ ${ }^{1}$ International Studies and Economics, Washington College, United States \\ ${ }^{2}$ Boğaziçi University Istanbul, Turkey \\ ${ }^{3}$ Al Akhawayn University, Ifrane, Morocco
}

Copyright $\odot 2017$ by authors, all rights reserved. Authors agree that this article remains permanently open access under the terms of the Creative Commons Attribution License 4.0 International License

\begin{abstract}
The political principle of Laicism was institutionalized in the constitutions of both France and Turkey supposedly establishing the separation of religion and state. This project seeks to identify whether French Laïcité and Turkish Laiklik have ever implemented Laicism in ways that fully separate the church and state and if so, to understand at which critical periods their comparability as assertively secular nations derailed. Although French and Turkish Laic-values are built upon a similar platform of nationalism, similar factors influencing the corrosion of Laicism in each case have produced inverse results regarding secularism in the contemporary. Confronting the notion of 'dual laicism's' I claim instead that both France and Turkey have undergone roughly similar processes since the birth of Laicism in each context but have been alternately shaped according to the dynamic interaction between prevailing ideologies of the dominant politic, society's perception of national value and national narrative. The fundamental difference between France and Turkey is more poignantly the direction of Laicism's corruption than the intensity of it. Have French Laïcité and Turkish Laiklik ever implemented Laicism in ways that fully separate the church and state, and if so at which points did they deviate?
\end{abstract}

Keywords Laicism, Assertive Secularism, Nationalism, France, Turkey, Religious Mobilization, Religious Politicization

\section{Introduction: What is Laicism}

Ferdinand Buisson first introduced the concept of Laicism in 1870 to mean " a secularist state, neutral between worship, independent of clergy, and disengaged from all conceptions of theology." [1] This separation of church and state has characterized the French republic (from 1880 to present), although three other constitutionally Laic states exist: Turkey (as of 1923), Portugal (as of 1834), and the
United States (1776). According to Kuru, Secularism, the "mother and father" of Laicism, establishes a system in which legal and judicial processes out of religious control, and where there is neither an official religion nor atheism. However, he also cites a distinction between freedom from religion (assertive) and freedom of religion (passive) in socio-political contexts. While passive secularism 'attempts to maintain neutrality,' an assertively secular state actively excludes regions from the public sphere, as a comprehensive doctrine. [2]

Despite the implementation of Laiklik as a pillar of Kemalism, it was instituted after the Young Turk's commission of genocide against Christian Armenians, and persecution of Christian Greeks and other ethnicities, which compelled them to go into exile. ${ }^{1}$ Turkey had offered refuge to Jews expelled from Spain and Portugal in the late 1400s, and many remain in urban areas like Izmir. The grim reality is that by the time Ataturk offered Laicism, the actions of the prior government ensured that Turkey's Muslim demographic equaled $98 \%$ of its population. One might argue that Ataturk was comfortable with Laicism because the Young Turks had ensured, via genocide and expulsion, that this liberty would not entail any meaningful religious diversity. The assumption of Turkey as 'benignly Islamist' or France as 'perfectly Laic' is flawed because it ignores the extremely shifting nature of identity as scripted by national narrative and the values promoted by it according to the rise and fall of dominant political ideologies who mediate them.

While it may be far-fetched to argue on behalf of similarity given that their contemporary positions toward Laicism and secularism fall on opposite ends of the spectrum, it is not unwarranted to place Turkey and France in a comparative. Born amidst similarly volatile environments, both cases are underscored by a deep sense of nationalism,

1 Amidst the collapse of the Ottoman and aftermath of WWI, Laiklik was one among five other principles institutionalized by Atatürk which were later dubbed "The Six Arrows of Kemalism" (Nationalism, Populism, Republicanism, Laicism, Transformations, and Statism) intended to unhinge the caliphate and sultanate that had historically ruled the region. [3] 
strained associations with 'modernity,' and counter-intuitive concessions of socio-political volatility. The fact that their paths have diverged so much from the central vein of Laicism (strict separation between the church and state) in the present is cause for greater attention, not less.

\subsection{Laicism in Contemporary Literature}

The literary gap that I intend to fill is one, which is actually newly formed in the last 15 years after the rise of the Turkish AKP to administrative and parliamentary power. In many ways, Laic discussions have long included perceptions of "dual Laicism's" under the pre-text that one country's implementation is false (Turkey), the other being the standard (France) as implicitly 'true' whether or not its application of the principle violates its fundamental values. In practice, it is this assumption is false. In placing Turkish and French Laic principles, we see a number of similarities in the formative stages of Laicism, which have created not a flat dissimilarity, but a similarly intense initial environment which lent the republican values it projected to be gradually corrupted by legislature revised in favor of specific contemporary power holders. While the birth Laicism is comparable in France and Turkey, it has evolved to inverse ends. Their greatest difference lies in the direction of political momentum (France moves toward hyper-secularism, and Turkey toward religious fundamentalism). Even so, this is not necessarily a one-sided disintegration of secular value. ${ }^{2}$ Thus far, I have found few sources acknowledging the deficiencies of French Laicism, fewer still who try to unpack the key moments in the timeline of Laicism in the Turkish context, and no other which juxtapose the concept of Laicism between them as I intend to do. My hope for this project is that it begins to acknowledge an underrepresented aspect of the present base of literature, and prompt the reader to question current conditions: given that Laicism was born from similar conditions, why did France become hyper-secular and Turkey abolish Laicism entirely?

While the hypothesis and research questions are my own, I intend to build it upon the concepts defined in Jeremy Gunn's and Ahmet Kuru's writings. This comparative case study will assess Laicism as it has evolved in Turkey and France furthering Kuru's hypothesis of assertive secularism and in accordance with Gunn's definition of Laicité. [4] On these grounds, Laïcité and Laiklik: Have the Ever Been One and the Same, will link the two larger conversations associated with the separation of church and state in France and Turkey based upon observing literature produced by three groups of writers: native French citizens, native Turkish citizens, and third party international intellectuals.

Notable authors in the French discussion: such as Alain Seksig, Fouad Alaui, Jean Baubérot (the only dissenting

2 It should be noted that this assumption of 'dual Laicism's' fails to acknowledge the disproportionate supply of western-centric literature hyper-polarization of 'East' versus 'West' and misconceptions that equate democracy with secularism. [5] vote regarding the Stasi Commission's headscarf ban), Debre Jean-Luis, and Ducomte Jean Mihel. ${ }^{3}$ These authors discuss Laicism on the political terms, which I will be forwarding throughout my analysis. Each of the authors are French nationalists, and I intend to review their work in French where possible. The national context in which they write is largely influenced by the fact that France harbors the largest Muslim population, and feels its culture threatened by this. For the sake of perspective, I've selected authors on contrasting sides of this dilemma and from journals of varied political leanings. The literature amongst this demographic is useful and plentiful, because Laicism has been heavily contested in political, philosophic, and academic forums. The swinging of the pendulum towards hyper-secularity in the contemporary warrants the re-calling of authors from 19th century to present. Further, the validity and substance of these works can be complimented through various media outlets, such as French news outlets, such national journals like Le Monde and broadcasting companies like France 24.

This project would be incomplete without recognizing the inspirations of Boğazici Professor, Political Scientist, and author, Murat Akan, who offered me my first blunt look at the implicit corruption of the church-state relationship through manipulative domestic policies. Throughout my research I have also analyzed readings from another former Boğazici professor of the same field, Parla Taha, author of Corporatist ideology in Kemalist Turkey: Progress of Order? Other authors such as Cemal Karakas (Turkey: Islam and Laicism between the Interests of State, Politics, and Society) and Syante Cornell (The Rise of the Diyanet: the Politicization of Turkey's directorate of Religious Affairs) directly confront the issue of the abused church-state relationship in Turkey. While authors such as Akan, Karakas, Kuru, and others publish in both Turkish and English, there is a large segment of literature which I do not have access to. One demographic that is strikingly absent - at least amongst the English publications - is the politicians and Imams themselves. Two interpretations of this silence are a) either they see little need to engage English speaking audiences or b) a truly spirited analysis of the separation between church and state does not cast a favorable light the interactions between these groups.

One of the most striking aspects about the body of translated Turkish works is that a majority of the literature - even after Turkey's transformation away from assertive secularism - had not begun to critically update itself until the stark reality-check of the 2016 attempted coup. The assumption that Turkey remained assertively secular was taken for granted even by highly acclaimed, extremely

3 Respectively, the specific works by the aforementioned authors are: "Ni plurielle ni de combat: La laïcité"(Neither pluralist nor [up for the] Fight: Laicism), "Des conditions de l'intégration de l'islam dans le cadre républicain" (Conditions of Islam's Integration in the Republican Framework),"La Commission Stasi: Entre Laïcité Républicaine Et Multiculturelle" (The Stasi Commission: Between Republican Laicism and Multiculturalism), "L'islam nationalisé?"(A Nationalist Islam?), and "La Laïcité" (On Laicism). [6] 
qualified political scientists and scholars. This continued well beyond the beginning of actually fall from Laic-Secularism largely because the targeted decline of this national pillar was not a process which drew mass amounts of media attention. In other words, major warning signs went unnoticed and did so with serious consequences.

On the topic of Laicism specifically, many Turkish authors have discussed Laicism as an innovation of Atatürk, a national value, and a strict paradigm enforced by the CHP for over 60 years. In contrast, few non-Turkish, western-academic writers acknowledged the discrepancy between Laicism and Secularism. For more representative information, it is often much wiser to review the work of various on-the-ground writers, such as expat journalist on the ground in Turkey who typically goes by the simple pseudonym, "James," and frequently posts to a blog site titled, "James in Turkey." [7] His frequent analysis and graphic mappings political party has been valuable to conceptually organizing the metamorphose of the Turkish Electoral and Parliamentary bodies. Additionally, Penny Green, British citizen and Turkish analyst, has written several works including, "Disaster by Design: Corruption, Construction and Catastrophe" which attest to the paradox nature of Kemalism in Turkey. [8] Carol Midgdalovitz provides an in depth analysis of Turkey's 2007 Elections and comments on what she terms a, 'crisis of identity and power' in the CRS-sponsored Report for Congress. Similar concerns are echoed in Katherine Wilkens, "Turkey: Emerging Regional Power or State in Crisis?" [9]

Just under a decade later, Ahmet Kuru's work, "Passive and Assertive Secularism: Historical Conditions, Ideological Struggles, and State Policies toward Religion" became a highly circulated article in democratization studies. Kuru articulates the typologies of his three secular case studies: The United States, France, and Turkey. Kuru's analysis of three 'model' secularist states depict Turkey and France as linked via a shared dominance of assertive secularism in contrast to the United States, which has generally gravitated toward passively secularist policies, is extremely interesting given that circumstances have drastically shifted since the time of the article's publication. (e.g. Figure 1. Methods of Difference and Similarity: U.S. France, and Turkey. Excerpt from Ahmet T. Kuru's Passive and Assertive Secularism: Historical Conditions, Ideological Struggles and State Policies toward Religion." World Politics 59 (4)). [2, 10, 42]

Throughout his works, Kuru wrote highly detailed analysis' on Turkish secularism and the perspectives one might adopt when comparing the ideological struggle implicit in developing state policies (Modernization Theory, Civilizational Approach, Rational Choice Theory) He also addresses shared aspects between France and Turkey, such as the presence of an 'Ancien Regime,' 'Critical Junction,' and an 'Ideological Path Dependence.' Despite the de-evolution of Turkey's church-state separation, Kuru's insights are integral to the examination of Assertive Laicism, as opposed to Passive Laicism, in Turkey particularly. Kuru's primary policy research concerns are consolidated within Education policy. He also illustrates the dominance of Assertive Secularism in both France and Turkey by comparing the permissibility's and limits of legislature on student religious dress, display of religious symbols, the acceptability of pledges recited in public schools, legality of private religious education and religious instruction in public schools, public funding of private religious schools, and prayer in public schools. While I do not equate Kuru's Secularism with Laicism, he identifies crucial contributing factors to the scholarly conversation on this subject. Kuru also acknowledges that even with apparent simplicity of secularism (separation of church and state), scholars may approach it differently depending on the regional influences of the place they focus.

To my knowledge, Dr. Jeremy Gunn is the most prodigious author in defining Laicism, as opposed to secularism, as well as its origins. He is frequently cited as a lead expert in many the Western and Eastern sources. His articles on the subject (written and published in both French and English) include but are not limited to such titles as: "Fearful Symbols: The Islamic Headscarf and the European Court of Human Rights in Sahin v. Turkey, "French Secularism as Utopia and Myth," "Under God but Not the Scarf: The Founding Myths," and "Religious Freedom and Laïcité." Gunn qualifies Laicism as a multivariable principle not developed until after the French Revolution. He references Laicism as evolving by the very virtue of conflict: "[T]he doctrines of laïcité and religious freedom are frequently employed not in the idealized way that the myths might imagine, but in the confrontational and polemical ways in which they originally developed." [11] On the grounds laid by these authors, this comparative case study compares Laicism as it has evolved in Turkey and France during similar stages of secular interventionism in accordance with Kuru's hypothesis of assertive secularism and Gunn's definition of Laicism. [4]

\begin{tabular}{ccccc}
\hline & \multicolumn{3}{c}{ Alternative Explanatory Variables } & Dependent Variable \\
\cline { 2 - 5 } & $\begin{array}{c}\text { Economic } \\
\text { Development }\end{array}$ & Civilization & $\begin{array}{c}\text { Dominant } \\
\text { Ideology }\end{array}$ & $\begin{array}{c}\text { State Policies } \\
\text { toward Religion }\end{array}$ \\
\hline U.S. & high & Western & passive secularism & inclusionary \\
France & high & Western & assertive secularism & exclusionary \\
Turkey & moderate & Islamic & assertive secularism & exclusionary \\
\hline
\end{tabular}

Figure 1. "Methods of Difference and Similarity: U.S., France, and Turkey 


\subsection{The Development of Laicism in Turkey Relative to France}

Despite its once reputation as 'the unique example of democratization,' this mode of popular representation was never a central aim of laicism in Turkey as it was for the establishment of laicism in France. [12] "Turkey appeared to many to be an important secular, pro-Western, democratic 'model.' In the U.S. - and to a lesser but growing extent in Europe - Turkey came to be viewed by policymakers as the country that occupied the "new front line of the post-cold war era." Contrary to these somewhat superficial perceptions, Turkey is politically more comparable to the organically statist systems more strongly associated with Latin American politics of the 1980s than to the Eurocentric model. While Turkey possesses every capacity to be a positive regional power, it commits itself to crisis. Political instability paired with the dominance of politicized Islamism, fluctuating economics, and skewed political equilibrium after the 1980 military occupation has resulted in the wholesale sacrifice of Laicism and other founding values. [13] According to Parla and Davison adhering to legitimate principles of Laicism would necessitate, "the expulsion of religion from certain spheres of governance and social life, the reconstitution of education according to the presupposition and aims of the positive sciences, and the establishment of uniform, nonreligious laws of a centralized administration..." [14] These incongruences increased in the latter half of the $20^{\text {th }}$ century where this project focuses its research.

The question is also extremely relevant to minority populations in both France and Turkey. The contortion of Laicism in practice rather than principle has significant exclusionary effects, particularly upon demographics deemed political minorities in Turkey (Alevis, Kurds, Women) and religious minorities in France (Muslim, Jewish, and Protestant individuals). In both contexts, marginalized immigrants and minority ethnic groups are further limited because of legislature enacted which staunchly enforce laic secularism (as by political vigilantes in France) or in disregard of the institutions which guard it (as in the rise of Islamist parties and economic coalitions in Turkey).

Although the 'Secularism' and 'Laicism' are often equated, Laicism represents the degree of strictness regarding the church-state within a secular state, or one presumed to be so. ${ }^{4}$ While a secular state is simply a state without a state religion, Laicism extends this concept to encompass the nuances of this separation. Likewise, embedding such a specific church-state relationship in founding documents as a national value harbors

\footnotetext{
${ }^{4}$ Beyond the assumption that 'secularism' is the colloquial equivalent of 'laicism,' another reason why secularism and laicism are often mistakenly viewed as interchangeable is translation error, For example, Laïcité, and laiklik each translate equally into Laicism in English. Likewise, laïcité translated to Spanish is lacismo. However, 'secularism' is also lacismo. Considering all texts in all languages, and all translation in academic circulation how many circumstances such as this are unaccounted for? [15]
}

implications beyond simply being etymological cognates as the words Laicism, Laïcité and Laiklik might suggest. Turkey's implementation of Laicism was, for nearly 60 years, reminiscent of French Jacobinism.

Evident similarities exist between France and Turkey as late as the latter half of the 20th century. The degree to which laicism (laïcité in French, laiklik in Turkish) diverge from legitimate church-state separation are dependent upon first why religion is politicized, and secondly why it is mobilized in France and Turkey's respective state building. Additionally, policy making in response to assertive secularism and secular interventionism acted as a rigid framework for policy structure during highly formative time periods-even if those structures have since been modified. [2] In the name of national preservation, Laicism eroded in both the Turkish and French contexts-first instrumentalized and then overshadowed by the cause it had been mobilized to represent.

\section{France}

\subsection{National Values: Laicism, Homogeneity, or Fear Driven Nationalism?}

Although both France and Turkey write their identities based upon Laicism, their differing contexts and objectives foster different perceptions of threat. It becomes clear that Laicism is an elevated value - not an implicit one - when one notices that none of the three fundamental pillars of the French republic (liberté, égalité, and fraternité) have been as hotly contested as Laicism despite their arguable corrosion. Where is true liberty in the face of a pervasive fear of terrorism, where is equality in the face of minority marginalization, and where is brotherhood in the absence of resources for the suppressed and refugee classes? In its place, 'Laicism' is declared under attack and fanatically pursued. In context of external pressures on domestic peace of mind, the contemporary threats that endanger France are not perceived to be detrimental to the political or territorial survival of the nation, but rather survival of its national culture.

Today French Laïc Secular values are maintained almost wholly via national identity, integration, and expected homogeneity. National preservation is so valued that when this uniformity was perceived to be threatened (as in L'Affairs du Foulard), both religious and conservative parties adopted a similar exclusionary platform, the first cross-party coalition in the nation's history. In the post WWII era, France, as 'The mother country' acquired immigrants who largely European and perceived as non-threatening to the national identity. As a result, 1945-1973 was dubbed the "Trente Glorieuse" (Glorious Thirty) for its lack of domestic tensions. ${ }^{5}$ French conflict

5 Although domestic social tensions were minimal, the French had 
involvement took place beyond its borders, and thus, domestically this was an era of limited social baggage. Today's social turmoil stands in stark contrast. A number of self-initiated factors, such as guest-worker programs in the 1960s and the colonial links in the Maghreb, paired with a perfect storm of global conditions premeditated this turmoil.

Following the havoc of World War II, reconstruction efforts continuing through the next decades resulted in widespread guest worker exchanges from the Near East. Newcomers filled a labor vacuum present not only in France, but throughout Europe. Receiving nations welcomed them under the assumption that workers would simply wipe their hands clean and return home after they'd served then had served their purpose. Sending nations exported either delinquent members of society or their surplus of unskilled workers. At this time in France, the image of the new migrants would have been one of an 'Islam d'hommes seuls.' An 'Islam of only men,' implied temporary migration and working to send money home to one's family. Both underestimated the long-term effects of bilateral labor exchange. As this image was progressively replaced with an 'Islam du families' (Islam of the family), a much more established immigrant network developed. Although 'migrants' became 'immigrants,' the French administration maintained the stance it held under former assumptions of impermanence. In actively rejecting integration, they also missed an optimal opportunity to do so.

At the height of the guest worker programs, French colonialism receded from North Africa. Surges of independence among previously 'subject' states gave rise to new fear-based discriminatory language, such as labeling the motives of newcomers to be in the name of 'Puissance Musulmane' or 'Muslim Power.' [16] After the independence of its former subjects, particularly north African immigrants would have been seen as 'former enemies and combatants allied with all the stigmas of the war the French had in truth, just lost. ${ }^{6}$ Even after the decline of colonialism, French Muslims were still not perceived as citizens, but as subjects-lingering beneath stigmas of the former Code de l'Indigénat. ${ }^{7} \mathrm{~A}$ series of socio-economic crises beginning in the mid-1970 produced a third shift in immigration politics, which widened the economic inequities between immigrants and the mainstream French.

While the first generation of immigration may have fulfilled a formal need initiated in large part by French

instigated imperial wars during this time in an effort to maintain a waning colonial influence. Most notably these wars were: Algeria 1954-1962, Morocco 1956, and Tunisia 1952. Each of the aforementioned gained their independence during this time. [16]

6 New demographics were viewed in a significantly more 'foreign' light, contrary to the predominantly European immigrants that re-settled as a result of displacement caused by World War II. [18]

7 The Code de l'Indigénat, or "Code of Indigenous," is often known informally as the French equivalent of the Jim Crow Laws. First implemented in Algeria in 1887, they were later applied to all territories in the French empire. The laws were abolished by the end of WWII. [18] government, this initial welcome was revoked leaving workers and their families at a loss as to whether to pledge allegiance to the old homes they could no longer return to or the new ones which now rejected them: "A whole labor culture loses little by little it's utopian objectives which gave him (her) hope and pushed them to a political commitment." [17] Implicit discrimination seeded resentment, which was only acknowledged long after its consequences began to unfurl.

Muslim immigration is neither new nor phenomenal. ${ }^{8}$ Rather than acknowledging their arrival as a byproduct of historic links initiated by the imperial efforts of the French themselves, many second and third generation immigrant communities however remained excluded economically and socially from the central strata of French society. [16] The prospect of resolving the integration of these peoples was further hindered after immigrants were further stigmatized following the establishment of the Islamic Republic in Iran 1989. ${ }^{9}$ Khomeini's re-installation of fatwa, mandatory veiling of women, and the condemning of writer Salman Rushdie to death aggravated existing domestic tensions in France associated with the dissolution of homogeneity. The exclusionary measures taken on behalf of France in the name of Laicism are largely interpreted as a strongly nationalistic response to a threatened cultural identity. In recent years, increased numbers of asylum seekers and refugees from former colonial and other regions amplified the discontent on both behalves. Although immigration and integration is frequently cited as the very crux of contemporary tensions, ultimately it is former administrative desires laid the groundwork which is currently undermining the very focal point of French equilibrium: homogeneity.

It would seem disrupting such a deeply seeded culture of uniformity is viewed as a greater threat to national security than the tensions introduced by extreme racism, economic stratification, minority marginalization, and poor refugee crisis management. Today, nationalism in France manifests itself alongside a fear of 'external' Islamism invading 'internal' domestic space, a blame that has been assigned to

8 Implicitly, France and North Africa were linked through shared linguistics, former French-initiated co-optation of elite North African populations, and vacuums of instability left in Maghreb countries following North African independence. In Tunisia, French actions to establish an elite class within Tunisia in order to maintain control. In the post-colonialist world, old elites sought refuge and upcoming elites sought the status of sending their children to Europe to receive an education. Morocco, once a French territory, developed a sovereign monarchy markedly distinct from the French Republic, but aftereffects of the "French Ideal" upon the Maghreb psyche linger through contemporary decades. [16 ]

9 Fear that Turkey is becoming not the next Egypt (where extreme social tensions are kept in check by autocratic rule), but the next Iran (which reverted from secularism to Islamism after the 1979 Revolution). The fall of secular Iran to Shiite Rule was influential in the destabilization of the entire region, as its Sunni neighbors perceived it as a threat the way a population might view a dormant volcano becoming active. Turkey is one of the single largest outlets for refugee passage to Europe, and with Erdogan's increasing permissibility to ISIS and active promotion of religious-based nationalism, this increases security risks not only to France but the whole of Europe. [19] 
immigrants, ethnic minorities, and Muslim populations. As international conflicts tap into the discontentment of their own marginalized populations, perceptions of threat reignite, and legislation pushes more strongly against diversity. In turn, new levels of disadvantages cascade - again - to a very targeted demographic of ethnicities, religions, and have been shown to adversely affect women of equally targeted immigrant origins.

With that said, immigration is not the 'cause' of a church-state relationship one way or another nor is it the reflection of it. The tensions posed by massive influxes of people are a catalytic juxtaposition of what is 'in' and what is 'out.' By this logic it is more understandable that the evocation Laicism should supersede liberaté, égalité, or fraternité. Laicism can be wielded to be far more exclusionary to groups identified as threatening. One can keep liberty, equality, and brotherhood, however one can passively keep, however one can (and should according to the French government) actively protect the 'sanctity' of Laic church-state separation.

\subsection{Effects of the French National Narrative on Public Policy Paradigms}

Socio-politically, it is widely acknowledged that the individual is the cement of civil society, but what happens when societal psyche splits? Implicitly, the French citizen is exposed to two national narratives, consequently the identities of 'Two France's.' Whether citizens conceptualize their nation's birth as simultaneous with the birth of the ancient church (i.e. a 'France by the grace Catholicism') or in conjunction with the birth of human rights in 1789 (i.e. a 'France allegiant to the Republic') dictates not only their interpretation of historic values but how these values manifest in response to contemporary challenges. However, each posits a stance toward Laicism which is in contradiction with the other. Although subscription to either identity is often an unconscious decision, recognizing these perspectives integral to understanding the phenomena behind the near unanimous support for Laic legislature present. L'Affaire du Foulard and The Stasi Commission represent the only cross-party coalition in French history (from either narrative's beginning). Even so, the country remains divided by a combination of self-perception and post-revolutionary roots.

The 'Catholic' and 'Republic' narratives propagate ideals historically warring with each other. A truly Laic government can only uphold the values of the latter narrative, never both. However, when confronted with mass migration, global terrorism, and social unrest, public policy (from the 1980s onward) began to manifest in ways which simultaneously reaffirmed both narratives-simultaneouslyunder the auspice of intensifying its rejecting religion. "They [Policy Makers] build a coherent narrative of continuity by passing over what they see as a contradiction, namely that the 'modern arrangement' of separation of religion and state was mobilized by defenders of religion." [20] During recent periods where Laicism has been highly politicized, Laic-inspired legislature has received near unanimous support from proponents of both religious and republican paradigms in spite of the fact that one paradigm may only truly exist in the absence of the other. Being the first cross party coalition of this kind in French history, this situation prompts the observer to question: to which camp do contemporary French citizens generally belong? Are Anti-Islamic undercurrents equitable to pro-Catholic paradigms?

Framing social policy in terms of social values - which have already been bent once in order to accommodate two historically incompatible mindsets - one can't refrain from critically questioning whether Laicism has truly been invoked to protect the public space from private space- or something else entirely. What specifically does legislature reaffirming laicism protect? Which values are perceived to be under attack? In the presence of pluralist contributions to social unrest, it becomes all too easy to cite immigrationregardless of legal, undocumented, asylum, or refugee status - as the 'cause' of domestic insecurity. What this simplistic perspective fails to acknowledge is that mobility is not the issue, but the tensions which drive it. In effect, touting laicism as the end-all value to be guarded at all costs as a means to combat these insecurities is a misappropriation of energies better spent actually addressing the tensions which facilitate extremism. Among the factors deepening this political divide are discrimination, economic disparity, callous treatment of ethnic-gender relations and half-hearted efforts to integrate immigrants and their descendants, as well as global variables beyond domestic control. Returning to the concept of national narrative defining national identity, citizens of North African descent and their children and grandchildren subscribe to the latter values instated by the Laic republic. The fact that they remain in the minority on the issue of Laicism suggests that a majority subscribe to the identity of France in terms of Catholicism. It is beyond paradox that laicism should the tool reinforce dominant religious identity.

State interest to control the composition of its citizenry escalates its involvement in private affairs. Excluded populations within France typically consist of non-Catholic individuals (predominantly of Muslim origin), immigrants, and increasing numbers of undocumented migrants, refugees, and asylum seekers residing within the country. ${ }^{10,11}$ More recently, the French National Assembly

10 In Turkey, the majority of official immigrants ranks Germany $(23,330$ people in 2015), France $(6,289)$, Austria $(4,476)$, and United States $(4,144)$ It should be noted that these numbers do not reflect refugees and asylum seekers). ([21-23] https://stats.oecd.org/Index.aspx?DataSetCode=MIG\#) [21-23]

11 Over the course of 2016, according to EC Europa statistics, the largest numbers of individuals seeking asylum in the EU come from Syria (102,350 people, or $36 \%$ of asylum seekers), Iraq $(35,045$ or $12 \%)$, Afghanistan (34,749), Pakistan (11,690), and Iran (9, 575). Other countries such as Libya, Algeria, Ethiopia, Morocco, and stateless individuals are 
adopted an immigration bill which attempts to encourage the reception of legal immigrants and skilled workers as well as manage immigration more efficiently. [24]While the largest numbers of official immigrants currently residing in France come from stable countries such as Germany, The United Kingdom, Switzerland, and Belgium these numbers do not reflect undocumented individuals, asylum seekers, and refugees making the dynamics of immigration in France undoubtedly more complex. ${ }^{12}$ Even with measures which slightly offset the structural disadvantages, excluded groups are excluded because they are viewed as counterproductive to the traditional 'French' identity-be that in accordance with Catholic Church or of the Republican national narrative.

\subsection{Public Sphere Politicization, Private Sphere Mobilization}

The full politicization of Laicism in France can be traced to catalytic events such Chénière's attempts to ban the headscarf in public schools in 1989, 1994 and then later formally with the implementation of the Stasi Commission, which was drafted in December of 2003 and implemented in 2004. The report addressed a range of issues including the Bankruptcy of Alsace-Moselle, private schools under contract, chaplaincies, rising anti-Semitism in certain schools. [17] Near the end of the report's 26 propositions, what became known as L'Affaire du Foulard or, The Veil Affair, dominated all media and social attention as it struck the chord of three sensitive tensions: the unintended consequences of colonization, Muslim immigration, and socio-economic crises. Why fear the cloth a woman chooses to place on her hair? Simplified further, The Veil Affair primarily concerned two principles: Immigration and Laicism. The Stasi Commission focuses on Immigration as a central cause to these tensions. These fusion of these elements resulted in the social re-assignment of the veil as symbolic of Islam's integration into French society rather than a simple religious symbol worn by an individual woman. The spontaneous adoption of 'threatened Laicism' as a rhetorical device is, upon further analysis, an unnatural political maneuver assumed out of political convenience. The consequences of this politicization occurred to the detriment of individual students, particularly girls, on a religious basis.

estimated to number 93,630 , or $33 \%$, of asylum seekers in the last year. "The highest number of first time asylum applicants in the fourth quarter of 2015 was registered in Germany (with over 162, 500 applicants, or $38 \%$ of total applicants in the EU Member States), followed by Sweden $(87,900$, or $21 \%$ ), Austria $(30,800$, or $7 \%$ ) as well as Italy and France (both with over 23, 500, or 6\% each)." (Tables 1 Asylum Quarterly Report in Eurostat Statistics
Explained, http://ec.europa.eu/eurostat/statistics-explained/index.php/Asylum_quarterl y report .) [21-23]

$1 \overline{2}$ The data used for this publication are provided to Eurostat by the Ministries of Interior, Justice or immigration agencies of the Member States and EFTA countries. Data on asylum applications are collected monthly while data on first instance decisions are collected quarterly. Data are based entirely on relevant administrative sources. [22]
In media, the eruption of Laicism as a 'trendy' topic extemporaneously coincided with these events. In direct contrast to the references mentioned in the former section (such as 'The Islam of Only Men,' 'Muslim Power,' and to 'The Islamic Menace,') many victims hurt by legislature passed in support of stigma are school girls, the economically disempowered, and persons fleeing violence in their home counties. Political rhetoric capitalized on the social progression of aggression as Laicism became an attribute of the 'modern arrangement' of national unity. [20] Society's level of investment shifted as "[t]he Veil Affair arose to intervene at a moment when Laicism was no longer needed to defend against Catholicism and was available to confront a new adversary." [1] Once elevated to a national value, Laicism became the principal abstract standing in the way of the private sphere, protecting the public space for civil society. This manifested in a series of hotly contested debates over the public versus private sphere activities particularly public schools. Public education simultaneously became a battleground for integration, gender inequity, and the sanctity of public versus private space politically - all beneath the auspice of defending Laicism. Policies such as the Stasi Commission implemented in the name of Laicism inadvertently promoted increased disparities within religious, economic, and gender inequities. The result of all of this ripples beyond failed integration of non-Catholic populations living in France, but of Muslim girls themselves (no male wears a headscarf). Posited with the ultimatum to unveil (i.e. to renounce a deep religious value) or to continue their education, many, choose the former over the latter. Banning the headscarf excluded Muslim girls from their primary means of integration into French society: the public education system.

Pushed away from public school Muslim girls were implored by family members either to discontinue their education altogether, or transfer to private Muslim institutions. If girls did not go to school they then risked increased dependence upon existing hierarchies reducing their ability to be economically self-determinant. Limiting education makes girls more dependent upon their families and later marriage in order to sustain themselves. This in turn would lower women's education rates which would decrease not only their individual capacity for independence, but limit the class mobility of each family unit affected. Following ban of the veil, an upspring of private Muslim religious institutions changed the scape of the French education system. Existing financing structures in place to endow private Catholic institutions could not explicitly exclude Muslim institutions. For the first time in French history a significant demand for Muslim institutions existed which was met by a rapid construction of schools, and aided by 'catholic' policies. With the availability of an alternative, more families enrolled their children, male and female, into private Muslim institutions further isolating communities from the primary mechanism of French social integration. With no real intention of altering the public education 
structure on the whole (only the habits of the individuals attending them), this symbolic legislative reform prompted responses that actually increased the number of private religious institutions throughout the nations involving more foreign religious oversight agencies such the DIYANET (discussed in depth in the second case study). Since then, state interventions on behalf of Laicism and the public space have intervened in the miscellany of the private sphere so much so that the consequences of such actions have ricocheted back into the public sphere. Banning the veil appears to be a vain attempt to placate social appetite's for unrequited angst rather than tackling any facet of the significant the structural problems. In striving to endow its Catholic majority through this stance, the French educational system disadvantaged non-Catholics demographics, such as Jewish, Protestants, and growing Muslim demographics. Ultimately, the repercussions of 'symbolic legislature' facilitate deeply seeded inequity.

\subsection{Exclusion, 'Modernity,' and the Incomplete Enlightenment}

Implicitly this means of exclusion invokes gender, as men do not wear hijab. Despite the projected equality of women and men in France, themes of gender marginalization are present through many levels of the French politic. Martone argues that despite supposed gender egalitarianism, French presidential candidate's, Ségolène Royal, campaign in 2007 illustrates an intrinsic perpetuation of gendered politics in the French system. He remarks, "[t] his outcome was not intentional, but rather a reflection of how culturally compelled gender norms that maintain existing power relations had hence, the current social order are internalized within members of French society." Spurred by the bicentennial of the French independence, the revisiting of what it means to be French drove many politicians enunciate what those values are, and to interpret them in all of the inflammatory ways which generate voters. Laicism, having already been elevated to a national value by the early 2000 s, easily lent itself as a dimension within discussions regarding secularism, racism, modernity, tradition, culture, nationalism, and gender equality. The 2007 elections, particularly, illustrate that the use of gendered ideologies-as well as Laicism's counter-productive role in this issue - is one which must be reconsidered. Likewise, if women's equality is remains an issue unresolved for those in line to lead the nation, how much more drastically does this affect marginalized demographics of women? Essentially, in politicizing her feminist cause, Royal's campaign fundamentally undermines it. Royal's discourse repeatedly references yet another controversial topic: modernity. "[T]he time for women imposes itself, like modernity ... [A] woman in power would push France beyond the outdated era in which it was trapped." [25] As Martone analyzes the platform of gendered discourse promoted by France's first female presidential nominee in 2007, Ségolène Royal, he finds above all that the French Republic Tradition has witnessed an 'incomplete enlightenment.' [25]

Post-election, Laïcité was already declining as a central issue in French politics. Although Nicolas Sarkozy would become the successor to Jacques Chirac and the Union for Popular Movement Party (UMP), over Ségolène Royal, with the Socialist Party (PS) souvent references to French 'modernity' bore an alarming resemblance to rhetoric used to justify the former French presence in Algeria (1827 to 1962). ${ }^{13}$ Under the pretext of liberating Algerian Muslim women, the French presented themselves as 'modernizing saviors.' However, [t]he French feared any space into which they could not penetrate, including the veil, and this most likely pushed them to encourage Muslim women to discard this garment." [18] Efforts to appear as 'emancipating benefactors' were often blatantly manipulative and pursued for the purposes of international image rather than the lives of the women whom they claimed to help. During this time, 'modernity,' targeted a specific population, but to some extent it replays in the debates regarding L'Affaires du Foulard (The Veil Affair). $[16,18]$ References to "modernity" sprinkled amidst political rhetoric (such as in repeated references Laicism and national preservation) not only indicate a groping for legitimacy, but should be accompanied by a major red flag. ${ }^{14}$

Thrust into contemporary contexts, what function does de-veiling women (or the state intention to mandate this) actually imply? As state priority to mold the composition of its citizenry increased, administrations became bolder in concerning themselves with and private sphere matters. Individual's identity was reduced to a 'state threat' along religious parameters. By catering to these whims, complex international security matters absorbed matters formerly left to individual concern. One has to question in what ways, specifically, does an individual woman's choice of dress threaten national security (or the principles that found it) particularly given that the literal fabric of the hijab does not hurt anyone nor promote harm in any way. Evidenced by the progression of aggression embedded in social rhetoric, the fabric of the argument against is however, is quite destructive. Banning veiled women from the public sphere, as initiated by the Stasi Commission, is fundamentally

13 Sarkozy ran on a platform of modernization and reform - taxes, global economy, relationship with the United. In contrast, Royal's platform promoted modernization via gender equality, improvement of the minimum wage, affordable housing guarantees, and a generally accepted stance that France should value its relationship with the United States without being intimidated by it. In the case of Royal's campaign, one could say that by embracing Bachelet's endorsement as a 'symbol of harmony,' she further promoted the traditional image of women rather than that of a progressive egalitarian force.
[26] (http://www.washingtonpost.com/wp-dyn/content/article/2007/04/13/AR20 07041301401.html).

14 Turkey has red flag indicators as well, however they are more strongly, associated with the military than political rhetoric. While politicians' influence upon instability may flare a reason for concern respectively, the military has more power than individual politicians. [28] 
counter-intuitive for a nation that not only desires but also prides itself upon setting the 'modern' standard of Women's Liberation. In fact, evidence exists that 'modern' motions to unveil Muslim women have had significantly adverse effects upon women of religious and ethnic minority by discouraging their presence to the public sphere.

Religion, as is mobilized particularly in the 1980s-2000s, was actively used by public political figures (for example, by Chénière) were wielded to garner a sense of nationalist solidarity and sway voters. Capitalizing on fear and insecurities posed by the rapid changes in the national population composition, the state justified its intervention by reaching into the private, particularly those of Muslim women, after banning the veil via the Stasi Commission enacted in 2004. Paradoxically, in being elevated to the status of a national pillar (in large part due to opportunistic politicians), the principle was reduced to a pithy rhetorical device. By the 2007 presidential elections, Laicism's hyper-politicization temporary declined in the absence of a need to mobilize ordinary French citizens only to be thrust onto center stage following the rise of domestic terrorist attacks early 2016. State need to mobilize political support and votes was fulfilled resulting in a brief fading of political and media attention after its millennium peak.

The spontaneous re-interest in unveiling and Laïcité may be the result of easy pickings trolled by politicians trolling public favor, but carelessly roused rhetoric can cascade into carelessly devised legislature bearing consequences which do contribute to aspects of domestic instability. While recent crisis may have compelled France to compliment isolationist tendencies with compromise, strong anti-Islamic undertones, which are negatively reinforced by the rise of global extremism and terrorism remain. As France is forced to accommodate spillover from international crisis, this inspires greater resentment from all groups involved, not less. According to Parla and Davison, "The Nation is a political and social whole that is formed by citizens who are connected with one another by the unity of language, culture, and ideal." [3] As the perceived threat of domestic diversity seemingly contradicts 'unity,' it is increasingly viewed as the cause of many national security issues. In response, the French politic hold more tightly to the values it has molded to ostracize such diversity.

Essentially, four central factors have led to the development of hyper-laicism we see today: dual-national narratives which develop dual value paradigms of identity, state and social desires to homogenize the French citizenry, and legislative reforms to integration institutions (such as the public education system), and a prevailing sense of threatened national security. Within these, counter-intuitive social policies are enacted by cross-coalitions in full support of Laicism in the abstract, failing to acknowledge the consequences of barring integration. At the crux of laicism's politicization is a hyper-awareness of the public and private sphere throughout civil society. This awareness is instilled partially by culture, volatile circumstance, and opportunistic politicians. In order to mediate these fears, citizens demand action on the part of the state that then prompt their intervention via legislature. Near unanimous support for such legislature 'rewards' politicians for igniting the issue in the first place... which then prompts them to revive the issue again for events such as elections. Social policy, passed according to social values, ebbs and flows according to state need and popular demand.

Set side by side, Turkey and France both enforce concepts of the public and private that have evolved from the time Laicism was born in either context. Implicitly both countries view diversity as a threat. While constitutional established laicism does install a formal relegation of the church to the private sphere in order to preserve the sanctity of the civil society's public space, laicism can and is also used as a key stone around which the body politic can unify en masse according to dominant political ideologies. In each, violations to laicism are visible via the misdirection of public funds to majority religious groups, the promotion of religious consolidation in state recognized groups, and the mobilization or demobilization of these variables at the will of both the French and Turkish State respectively.

\section{Turkey}

Although Turkey possesses every capacity to be a positive regional power, political instability paired with the dominance of politicized Islamism and fluctuating economics doomed it to be a state in crisis. [13] Despite its once reputation as 'the unique example of democratization,' this was not a central aim of Laiklik as it was for the establishment of French Laïcité. [12] "Turkey appeared too many to be an important secular, pro-Western, democratic 'model.' In the U.S. - and to a lesser but growing extent in Europe - Turkey came to be viewed by policymakers as the country that occupied the "new front line of the post-cold war era.' [28] Contrary to these somewhat superficial perceptions, Turkey is politically more comparable to the organic statism most strongly associated with Latin American politics of the 1980s than to the Eurocentric model. ${ }^{15}$ Despite the implementation of Laiklik as a pillar of Kemalism, it was instituted after the Young Turk's commission of genocide against Christian Armenians, and persecution of Christian Greeks and other

15 Literature representing each country is disproportionately non-local in origin, casting the nuances of the Turkish Laiklik in juxtaposition with a Western and often French 'standard.' This polarizes the situation into an ultimatum of democratic compatibility versus incompatibility, when in fact this was not the question Turkish Laiklik was implemented to answer. Amidst the collapse of the Ottoman and aftermath of WWI, Laiklik was one among five other principles institutionalized by Atatürk which were later dubbed The Six Arrows of Kemalism: Nationalism, Populism, Republicanism, Laicism, Transformations, and Statism intended to unhinge the caliphate and sultanate that had historically ruled the region. Whether or not these principles create a favorable condition for democracy is an issue beyond what will be explored in this comparative however important to address. More relevant to this analysis is where exactly this misassumption 'jumped the chain' of common understanding. [8-32] 
ethnicities that compelled them to go into exile. Turkey had offered refuge to Jews expelled from Spain and Portugal in the late 1400 s, and many remain in urban areas like Izmir. The grim reality is that by the time Ataturk offered Laicism, the actions of the prior government ensured that Turkey's Muslim demographic equaled $98 \%$ of its population. One might argue that Ataturk was comfortable with Laicism because the Young Turks had ensured, via genocide and expulsion, that this liberty would not entail any meaningful religious diversity. The assumption of Turkey as 'benignly Islamist' is flawed because it ignores three elements: (1) Laic Kemalist values were maintained through authoritarian enforcement, (2) reforms regarding Laic principles augment the power of the holder not the ideology they embody, and (3) economic volatility lends itself to both political re-ordering and the concession of freedoms.

\subsection{Solidarity through Authoritarianism: Kemalist Enforcement of Laic Values}

Since the 1950s, Turkey has undergone a significant economic crisis as frequently as once a decade. Frequent economic crises created grounds for government intervention that facilitated the eventual institution of the AKP government in exchange for CHP. The replacement of Islamic value in the role Kemalist traditions heralded the death of laicism - not the end of extensive government controls and authoritarian method. Under CHP autocratic method had been enjoyed by the dominant political powers, regardless of the severed coalition of church and state for over 60 years. Through successive constitutional rewrites, what has survived, what has been lost, and what has been strengthened in the tumultuousness of these instabilities clearly indicate the priorities of the military and state: Kemalism's preservation. Although the CHP would retain power for several decades after, the 1961 Constitutional rewrite prompted renewed calls for increased religious protection within the document. "... [R]eligious infrastructure came from the military itself, what is the self-declared heir of Kemalism. The military's actions in this respect underscored one more time that Kemalist laicism in Turkey embraces state mobilization of religion as a cement of society..." [12] Laicism as it is applied in Turkey does not seek to eliminate religion but to increase the level religion subject to state control. Thus, the Turkish system justifies increased association with its dominant religion, Sunni Islam, by claiming its "necessity." When religion falls beneath the nation, it will not oppose the nation, creating a situation in which the manipulation of Laicism produces an oxymoronic state of 'non-democratic patterns of religious-state relations.' This was the practice beneath CHP, and it is a tradition that has escalated with the current Islamic administration in power.

Nonetheless, in rhetorically pursuing secularism through the early 2000s, Turkey enjoyed the blind eye of Western powers regardless of the fact that its version of secularism is ensured by an entrenched autocracy. ${ }^{16}$ This context of frequent and sporadic economic crisis coupled with high motivations to 'modernize' set the stage for massive reforms. Implementation of reforms legislatively favored the already-empowered, as opposed to private or representative institutions. In practice, expediency won over representation. It is too late to question whether crisis and development will continue to be a "package deal" in determining Turkey's future. Crisis is already underway.

\subsection{In the Name of the Nation: Precursors to Political Restructuring}

In many ways the sanctity of Turkey's founding pillars has been morphed into a value exceeding the substance of Atatürk's 6 Arrows of in themselves: Republicanism, Nationalism, Populism, Laicism, Transformationism, and Statism. Beneath the facade of protecting Turkish Kemalist Identity, the conjoined image of 'the state' and 'the guardian' - equivocally presented by every administration regardless of their agenda - has also been an instrumental factor in undermining it. Those in power exert their influence upon the national values to the extent that they retroactively modify the pillars of the nation to suit their objectives or justify past actions. ${ }^{17}$ "The original term inkllpapçıllk was replaced in the 1935 RPP program with a Turkified form of the arrow devrimcilik, a term that is indeed more easily translatable as 'revolution." [3] Encoding 'revolution,' the more volatile mode of structural modification, in place of transformations as a national pillar foreshadows significantly more drastic swings in the political pendulum.

In short, structural alterations to the political system have tended to promote greater degrees of executive power expansion resulting in imbalance rather than stability. For example, Turkey's second military coup dubbed the "Coup by Memorandum" (1971) resulted in the banning of non-violent political opposition parties fostering widespread

16 Turkey has experienced four coups since its independence in 1923. The first military coup occurred in 1960. The Coup by Memorandum took place in 1971 , the third in 1980 (after which point the military ruled for three years), and lastly what became known as the "1997 Bloodless Coup" arose immediately after economic crisis and collapse. It would appear that the course of Turkish political progress and economic development is doomed to follow a dramatic ebb and flow. During this time, Turkey also pursued a number of economic initiatives. In 1960, Turkey ratified their membership in the Organization for Economic Cooperation and Development (OECD), making them a founding member (August 1961) just a year and a half after its first military coup in 1960. [21-23]

17 Revolutionism/Transformationism in 1921 established the state of Turkey (and with it Laicism) against western powers dividing the Near East, Mid-East, and North Africa. The essence of this arrow has been interpreted differently according the objectives of the entities using them, thus reflecting contradictory practices. Revolutionism (military uprising) overthrew and occupied this government from 1980-1983. Transformationism accounted for the parliamentary executions of opposition parties through the late 1990s - gradually shifting the legislative scape and consequently the environment of Turkish politics. Transformationism facilitated Erdoğan's rise to power. Revolutionism threatened it this summer. Technically speaking, both processes are both promoted by Kemalist ideology even if the stance against Laicism - the primary jewel of Kemalist thought - is subjective to the reigning party in power. [14] 
resentment against blatant unilateral enforcement of Kemalism. By the 1980s, MSP rallies in Konya against the welfare cutbacks romanticized the 1979 Iranian transformation, through anti-Kemalist slogans. While the issue was likely more attributable to the specific agenda of the administration itself, discontent manifested against the general ideology of the regime: Kemalism. [29] Both Western states and a large percentage of Turkish nationals demanded for military intervention to preserve secularism. [12] Given the unrest, it took little prompting on the part of the social democratic Republican People's Party (CHP) to push the government to collapse. Military intervention, when it came resulted in the institution of martial law for the next 3 years, compulsory voting and political 'cleansing.' [15] In the wake of the military coup of the 1980s, nearly the entire opposing Liberal Democratic Party was imprisoned or killed. Ultimately, this rewrote Turkey's political landscape, limited its representative capacity, and undercut Turkey's internationally "progressive" identity. Paradoxically, government agencies that facilitated increased nationalization of Islam during the 1960s as a means of containment were leaned upon to offset the ideological spillover of the Iranian Revolution and other highly religious sentiments seeping in from the Arabian states and Pakistan at this time.

\subsection{Political Reordering: Unraveling Laicism from the Top-down and Bottom-up}

In a state of post-crisis of the 1970s (and mobilized Islamism in government of the 1980s, a movement called the Turkish-Islamic Synthesis (TIS), gained popularity with ex-National Salvation Party(MSP) members whose party was dissolved two years prior in 1981 beneath the military's ban on political parties and whose ideology drew inspirations from Sunni Islam and Milli Gurus. TIS was also popular with former members of the short-lived Motherland Party (ANAP) which was a right wing party founded by Ozal in 1983 upon neo-liberal principles of economic conservatism. [7]

The ideological re-interpretation of Kemalism under the Turkish-Islamic Synthesis (TIS) implicitly promoted top-down Islamization by dictating both the existence and scope of freedoms allowed to Turkish political parties. ${ }^{18}$ Further still, the function of the Turkish military as a Kemalist counterbalance to TIS facilitates 'Sunnification' as a means of national solidarity and integration, re-allocating and expanding funding of religious government institutions such as the Diyanet playing upon tensions within the masses. "The ideological re-evaluation

18 Also known as the "Hearth of Intellectuals," the Turkish-Islamic Synthesis calls for centralization of power within the state, but against nationalist objectives. Despite its tension-ridden objectives, their popular influence riddled primed civil society prior to the military coup. TIS advocated authoritarian management of society guided by Islamic motifs. $[30,31]$ of religion and the expansion of state religious services were designed to create or 'buy' a spiritual compensation for material losses: the number of mosques grew from 57,000 in 1983 to 72,000 in 1987." [15] Even with an Islamic party in power, secular principles were initially held in tact, reinforced by the dangling carrot of EU ascension political adjustments that inadvertently 'enforced' Laicism more effectively than resentment-producing authoritarian measures offered by the formerly dominant CHP. However, this likelihood evaporated with Turkey's unwillingness to conform to EU mandates. Although Turkey's economic development has advanced since EU discussions in the 1990s, Turkey's desire to join the EU is laced with baggage and its political condition incompatible. Lack of confidence in eventual EU admission removed incentive to maintain aspects of church-state separation that once benefited their EU application. This drove national reforms increasingly in favor of Islamist party objectives. By the end of the 1980s, political Islam in Turkey was actively and openly promoted - both from top down forces (through politics) and from the bottom up (through growing public mobilization). ${ }^{19}$

Formerly, the military painted its endorsement (and enforcement) of the nationalist, Kemalist version of Turkish identity as protecting rather than oppressing, while radically deconstructing existing political institutions. "If one is to call their transformation a revolution one should at least be clear on this content and on the fact that, in the eyes of the Kemalist leadership, a large transformation was desirable, whereas a revolution-understood as radical transformation-was not." [3] Assuming that 'their' describes any person or party in the dominant seat of power, a transformation would further Kemalism in posterity, and revolutionism would threaten it. In creating a pretext for intervention the military's "strategy of tensions" would have serious political repercussions for the Turkish politic long after the end of their occupation that would eventually upset the balance of parliament so much that it would become but a tool to the executive it was intended to mediate.

After military occupation of the government ended in 1983, all parties capitalized on new liberties to revive and establish political parties. This political opening included representation of all whose political expression had formerly been stifled during the military seizure and the CHP dominance that reigned from Attatürk in 1921 until 1980 - namely religious conservatives, nationalist, and

19 The 1990s brought a new array of Islamist parties, including but not limited to the Democratic Left party (DSP), Social Democratic Populist Party (SHP) plus its Kurdish off-shoot called People's Labor Party (HEP), the right wing liberal-conservatist Motherland Party (ANAP), the center-right conservative True Path-DYP-NDP coalition after the abolishment of the center conservative MDP in 1987, the far-right IslamicWelfare Party (RP), and the ultra-national Nationalist Working Party (MCP). Surviving at the end of the decade. were three center left groups (DSP, CHP, HADEP), two secular center right parties (ANAP, DTP - a break away faction of DYP), two religious conservative parties (DYP, FP) and three nationalist parties (MHP, ATP, BBP). [7] 
representations of the center right. Two new left wing parties emerged from the former dominant CHP Republican People's Party (HP and SODEP), three secularist center right movements split from AP Justice Party (ANAP, MDP, and DYP), MSP National Salvation Party continued (Erbakan's followers remained united although RP was barred from running) and Türkeş's MHP followers regrouped beneath the name MP Conservative Party. [7] Because of the recent military reign, most members of left-leaning parties were imprisoned, executed, or banned from politics that skewed all subsequent political developments thereafter to the religious conservative right. With the backing of the military, Turgut Özal's Motherland Party (ANAP) continued economic measures initiated 8 months prior to the coup. He ended the import substitution politics and promoted export-centered growth. [32]The bulk socioeconomic transformation and liberalization is pursued at the discretion, ultimately, of the military, not the state. Increasingly, the military promoted Islam as a technique of placating the masses and, paradoxically, as a means of safeguarding Kemalism.

Other reforms enacted after the 1983 Parliamentary Elections expanded state-funded religious services, including the powers of The Directorate of Religious Affairs (known either by its acronym, DIYANET, or colloquially, the Diyanet). ${ }^{20}$ In direct violation of the Laic principles Parla and Davison define as "the expulsion of religion from certain spheres of governance and social life, the reconstitution of education according to the presupposition and aims of the positive sciences, and the establishment of uniform, nonreligious laws of a centralized administration," [14] the Diyanet defends a particular version of Islam, Sunnism, and in 2015 expanded its employee base to include near 85,000 clerics within its ranks. [12] Legally, stances offered by the Diyanet carry no weight as they are, technically, a religious management institution not a source of law. However, their increase in influence and activity has soaked up increased allocations of government funding. The Diyanet involves itself in all aspects of life, encouraging callers to harmonize their daily lives with the principles of Islam. ${ }^{21}$ The institution's principle concern is staffing mosques and religious education, however in the last five years significant structural re-adjustments have been implemented in conjunction with relaxed regulations. For example they are now no longer co-managed by the Ministry of Education,

20 The Diyanet was created in 1924 by the Grand National Assembly of Turkey after the abolishment of the Ottoman caliphate. Its survival through the 1961 Constitutional rewrite and the three military coups since indicates that despite Turkey's former secular interventionist reputation, the government-initiated religious directorate is here to stay amidst a wave of other religion-friendly reforms. [33]

21 Svante Cornell, "The Rise of Diyanet: the Politicization of Turkey's Directorate of Religious Affairs" in The Turkey Analyst, Section 2:

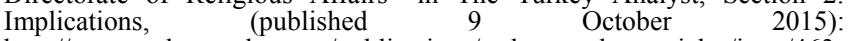
http://www.turkeyanalyst.org/publications/turkey-analyst-articles/item/463the-rise-of-diyanet-the-politicization-of-turkey's-directorate-of-religious-af fairs.html . [33] and qualifications to becoming an eligible teacher have been greatly reduced. These reforms have expanded both the liberty and scope of the Diyanet and increased their status in public debates. According to the same analyst referenced above, Diyanet telephone hot lines are available to deliver halal certificates and service 'fatwas on demand.' The institution even made international headlines in 2015 when it issued a fatwa declaring the acceptability of toilet paper by Islam: "If water cannot be found for cleansing, other cleaning materials can be used. Even though some sources deem paper to be unsuitable as a cleaning material, as it is an apparatus for writing, there is no problem in using toilet paper..." [34]The Diyanet possesses the capacity to intervene in all divisions of society, even gender (such as their decision to advocate birth control pills, permitting in vitro insemination, and allow the training of women as preachers). ${ }^{22}$ "Like many of Turkey's powerful state institutions, Diyanet constituted a check on political Islam as long as the state was controlled by the republican establishment. But once the state came under the control of political Islam, it became a handy tool for the propagation of this ideology." [32] This level of involvement by a state agency is unparalleled as it offers religious endorsements, pardons, and sanctions on a daily basis. Bolder statements by religious-political figures paralleled the state's expansion of Sunni-slanted State services: "Diyanet press releases have supported the introduction of greater Islamic themes in public education, and Görmez found it appropriate to warn the visiting Pope of the 'rising Islamophobia' in Europe. In 2015, he publicly called the Pope 'immoral' over his stance on the Armenian genocide." [33,35] In the eyes of the general public, Islamism was seen as a means to counter an unjustly heavy-handed military, which was equated with the Kemalist Secularism it ardently protected. Laicism, being one of the six Arrows of Kemalism, fell into the same hand basket of tainted associations.

Reflecting Turkey's desire to be an international economic contender, Turgut Özal's ascension from Prime Minister (1983-1989) to Presidency (1989-1993) paved the way for political reordering in ways which, namely through economic neoliberal reform policies. Through a succession of campaigns, he sought to employ internationally 'trendy' neoliberal relief measures, however these were weakly supported and proved largely ineffective against the extreme turbulence that ensued the following decade. ${ }^{23}$

22 The French also have a Diyanet structure although it was created not to supplement the prevailing religion, but to fragment an expanding one. The French Diyanet intentionally consolidates otherwise scattered religious authorities as a means of keeping them under the thumb of the state. By its very management structure, the Diyanet in France addresses a strongly polarized area of domestic concern: the coalition of religious force. In effect, the Diyanet is used as a foreign policy instrument to manipulate Islam in both in the originating (Turkish) and receiving (French) contexts. The only difference between them being that the Turkish Directorate of Religious Affairs is for religious mobilization and the French-based Diyanet is intended to demobilize and contain domestic religious movements. [26]

23 The 1990s were marked by economic crises $(1991,1994,1998$, and 1999), another military coup (1997), a 7.5 magnitude earthquake (1999), 
During his time, Özal lead by technocratic initiative rather than political ideology. Özal's death in 1993 had an equally dramatic (although often overlooked) effect on the governing political institution. "In an effort to retain their hold on power, the civilian leaders who had succeeded Özal granted increasing authority to the military over national security matters, in particular the country's raging war against Kurdish insurgents in the southeast." [28] Although Özal's elected party actually remained in power, his absence essentially opened the door complete overthrow. Hoping to maintain power after Özal's death, the ANAP faction continued to prioritize economic recovery and development, but handed over powers to the military in order to do so. As a consequence, political norms were violated, rewritten, and power had irreversibly transferred hands once more to the armed forces. This led to a military coup, later dubbed 'The Bloodless Coup of 1997.' After a series of scandals and the re-collapse of the economy, the expanding far-right Islamic Welfare Party (RP) enjoyed the image of a 'clean' political party. "No party has benefited more in recent years from growing public frustration over corruption than the pro-Islamic Welfare party [RP]." [28] Between 1987 and 1995, support for RP tripled from 7\% to $21 \%$. Islam was not only revisited in politics, but also ushered by increased fragmentation, corruption, and economic volatility.

\subsection{Violations to Laicism and the 'Modern Arrangement'}

Pro-Islamic power rested more strongly in parliament than the masses, which allowed them to push for dramatic institutional changes. In the immediate 1983 post military political re-opening, $30.46 \%$ of the power resided in center left parties, $87.55 \%$ with secular center right parties, $7.16 \%$ with religious conservatives, and $2.93 \%$ with nationalists. [7] Systematic execution of opposition parties dramatically skewed parliamentary balances. After the 1999 parliamentary elections (and a military coup in 1997), 35.63\% of the power rested with center left parties, $25.8 \%$ with secular center right parties, $15.4 \%$ with religious conservatives, and $19.04 \%$ with nationalists. Although the center left (largely rooted in the CHP) appears to have risen $5.17 \%$, over two thirds of their support base was killed, imprisoned, or exiled through the three years of military occupation which undermined the CHP's 62 year reign. "The executions of some members of the opposition sent an unmistakable message to others who might consider

the coalition of DYP and RP (an Islamist party union which collapsed in 1998) and the rise of DSP (center left), MHP (far right), and ANAP (right wing liberal-conservatist). Although Ozal's ANAP lost power to DYP in the 1991 Parliamentary Election, they remained a central opposition party who consistently prioritized economic reform. DYP (Center right conservative) also furthered economic liberalism. Ultimately, the perceived inability of either of them to truly remedy the economy caused increasing numbers to support alternative parties, particularly with Islamic origins in the religious conservative National Salvation Parti (MSP) prior to the military occupation. $[9,13,19]$ inheriting their role. It also confirmed that if any political openings were to occur, the regime would determine the time and manner on its own. Change, like power itself, would flow from above, an outcome of the will of the administration." [28] More revealing, is the fact that the share of parliamentary power held secular center right party members decreased $51.92 \%$ while religious conservatives doubled and nationalists grew tenfold. Political parties with nationalist and Islamic roots critiqued of US imperialism and called for the creation of an Islamic Nato, an Islamic Common Market, and an Islamic United Nations. At the same time, secular-laic principles resonated less strongly with masses who were disenchanted with previously dominant Kemalist ideologies. [28] By the turn of the millennium, religious influence had drastically increased in both government and socio-economics calling to question the value of Laic separation of church and state as a national value.

Similar violations of laicism, secularism, and other liberal values appear via the misdirection of public funds to majority religious groups, the promotion of religious consolidation in state recognized groups, and the mobilization or demobilization of these variables at the will of these respective states. "They build a coherent narrative of continuity by passing over what they see as a contradiction, namely that the 'modern arrangement' of separation of religion and state was mobilized by defenders of religion." [20] The persistence of disconcerting 'red flags' such as drastic declines in typical democratic indicators, such as the sharp decline in respect for human rights have done little to quell fears about Turkey's stability. According to the 1996 Annual US State Department Human Rights Report for Turkey, Extra-judicial killings, including deaths in detention from excessive use of force, in safe house raids, and 'mystery killings' continued to occurring with disturbing frequency. Disappearances also continued. Torture remained widespread; Police and security forces often abused detainees and employed torture during periods of detention and interrogation. Prolonged pretrial detention and lengthy trials continued to be problems. [28] Religion and nationalism have been mobilized simultaneously by power holders (via various auspices) in order to target political and ethnic groups. In 2007 for example, the assassination of Hrat Dink, Armenian Editor in Chief of Agos, the only Turkish-Armenian weekly publication, proved that longstanding minorities were vulnerable regardless of their status, position, or publicity. His murder was all at once an attack on free speech, an attack on minorities, and an affirmation of arrogance on behalf of those in majority power. In "managing" minority Kurdish and Armenian populations, the increased influence of the Erbakan-Ciller eras incrementally sidelined Atatürkian secularist foundations. ${ }^{24}$

24 In 1993, Tansu Ciller formed a coalition government with SHP, a left wing derivative of CHP, with the consent of newly elected then-president 
The Kemalist model of laicism is observably paradoxical, born of the rigid authoritarian enforcement it is currently caving into now. Conceptually, little difference exists in the institutional mobilizations of religion between Kemalists and Islamists. Rather, the difference between dominant secular and religious entities lies not in their methods of authority - powerful actors have always siphoned the natural flow of all political activity - but in who dictates the national identity, and consequently how they function, and what they allow. The violent decline of one powerful party (at the same time as an economic crisis) in exchange for an ideologically opposite party (at the same time as economic acceleration) opened opportunities for the new power to entirely deconstruct Turkish political institutions traditionally highlighting the separation of church and state. From this perspective, Turkish Laicism has been problematic since its conception.

\subsection{Contemporary Consequences}

With the rise of AKP at the turn of the millennium, citizens increasingly feared the loss of laic secularism and other Kemalist principles. The expiration of President Ahmet Necdet Sezer's seven-year term presented grounds for a historic presidential election in 2007. The AKP Islamic majority maintained a majority in Parliament since 2002, although their reforms had been consistently vetoed by the staunchly secularist Sezer. The end of his term signaled an immense opportunity to for the increasingly powerful AK Parti. Further, an embezzlement scandal within CHP paired with economic decline accentuated the CHP's loss public favor and influence, despite strong public suspicions over the implications AKP dominance in parliament and the executive. ${ }^{25}$ With the implementation of Recep Tayyip Erdogan as Prime Minister and Foreign Minister Abdullah Gul as the President-elect came political

Demirel. This coalition later collapsed in 1995. Through the next year, Çiller continued his role as 'care taker' of the party. After calling for a year-end election with the support of CHP, the parties were unable to agree on a secular coalition against the Islamic Welfare Party (RP) who ended up winning the election. Necmettin Erbakan, as the face of RP, became the face of the nation. He then formed a coalition with DYP, who had recently aligned with ANAP. Prior to the party's forceful closure in 1998 they possessed 158 of 550 seats in parliament. They reformed as FP, and were closed again by the Constitutional Court in 2001. Immediately afterward the Milli Göruş movement split, the more powerful faction headed by Recep Tayyip Erdoğan via the AK Party with 363 parliamentary seat of 550 after winning the 2002 Parliamentary Elections. [29, 36]

25 The Republican People's Party (CHP) also known as Atatürk's party, held power from Turkey's inception (1923) until the military seized power (1980). During Erdogan's 2007 campaign, the CHP backed by the military encouraged him to re-select a "consensus" candidate less controversial without blatantly overstepping the liberty of the majority party (AKP) to supply a candidate. After no replacement was presented in place of Abdullah Gul, the CHP under the direction of Deniz Baykal attempted to convince and coerce remaining parliamentary parties to 'boycott' the first round. To do so would not only rob the rising AKP of needed votes required to elect their candidate, but oblige an early election. Urban centers became home to unprecedented protest demonstrations against AKP power. Of 361 deputies in attendance, Gul received 357. After asserting that 367 attendees were required to make the first round of voting legitimate, they petitioned to nullify the first round of voting. [15] (https://www.fas.org/sgp/crs/mideast/RL34039.pdf) crisis. [9] Despite Gul's efficacy as a foreign minister and capacity to be the presidential nominee for AKP, his prominent activities in two former controversial parties (which were later banned) paired with the controversy presented by the fact that his wife wears a hijab made secularists in government wary of ulterior motivations. Prior to this, former president Sezer had refused to extend invitations to hijab-wearing wives of AKP members in Parliament for Çankaya Palace receptions because of the Turkish policy against the veil in public spaces. The ascension of the AKP to power was perceived as a direct threat to the balance of power. Although it was argued that if voters truly wanted to check this equilibrium they disrupt the party's majority in parliament by means of denying them a mandate in the 2007 national elections that November. In Midgdalovitz's report, “Turkey's 2007 Elections: Crisis of Identity and Power," she observes, " $[t] o$ some extent, the opposition Republican People's Party (CHP) is a party of the armed forces, bureaucracy, legal system, and academe, fighting to retain their powers and vying against AKP, a party seeking to expand its powers." [9] Recent events reaffirm the contest between the military and the administration (CHP, AKP, or otherwise). The flurry of actions taken upon executive order to ensure the survival of the Turkish state has swept aside its historic values, particularly that of laic church-state separation. Recently, Erdoğan's motions eliminate the position of prime minister, a position he held himself for a decade, would consequently strip parliament of its power and turn Turkey into presidential republic. Modifying the constitution has devolved into equal chaos:

"In one brawl, a government MP alleged an opponent bit into his leg. In another, a plant pot was hurled across parliament. A microphone was stolen and used as a weapon. An independent MP handcuffed herself to a lectern, sparking another scuffle. The parliamentary debate on changing Turkey's constitution wasn't a mild affair." [9]

In the wake of the 2016 attempted coup, Erdoğan draws upon Islam as a unifying force and seeks to formally expand his powers to permanize the privileges he has wielded since declaring a state of crisis. Secularity is not his only target, but intellectual classes, educated upper-middle classes, and violent and non-violent oppositions groups. By the grace of the 'modern arrangement' violations to laicism reflect the indefinite capacity of dominant state ideologies to mold national values claiming the national identity or composition that should be is one that always was. As top-down and bottom-up forces reinforce dominant ideologies - be they secular or religious - they accelerate deviations from Laicism present from the earliest stages of its modification. 


\section{Review}

\subsection{Similar Nationalist Tendencies, Inverse Church-State Results}

Returning to the namesake question of this paper in light of these starkly different environment, have French Laïcité and Turkish Laiklik ever implemented Laicism in ways that fully separate the church and state? Simply put, yes. This is apparent when one places side-by-side the initial overthrow of the Catholic Church and Mustafa Kemal's vision of an independent Turkey in 1921 in the vacuum of the collapsed Ottoman. One step further, if Laicism was developed through similar mechanisms in both France and Turkey, why do they occupy opposite stances with regard to church-state separation today? The methods of mobilizing religion in each of the contexts of this principle grew more parallel through the latter 20th century because of their shared deviation from a strict the separation of church and state (as dictated by secularism). In both cases, incremental top-level corruption of the church-state relationship has substantially contributed to the polar extremity of their respective attitudes today, in spite of their opposition.

Side by side each system is laced with violations, however prompted in inverse currents by legislature. The manifested political outcome is one of hyper-secularity and Islamization. This project sees to identify the critical time periods in which national narrative, value, and ideology were particularly influential in the inverse outcome between France and Turkey and how these elements dynamically interact with respect to Laic church-state separation. Given two countries where each of these units was stagnant for an extended amount of time, their deviation is a phenomenon. The contortion of the Laic value in both case studies reflects the elevation (in the French case) or deconstruction (in the Turkish case) of national values, according to civil identity, national value, and top-down projections of the 'ideal' citizen proposed by the state.

Simultaneous nationalism, religious persecution movements, and nation-state building generated a particular form of assertive secularism that elevated 'Laicism' to a national pillar, a national arrow. In the nascent years of laicism's development, this manifested as a widespread and brutal persecution, headed by the Jacobins in France and the CUP (Young Turks) in Turkey. As this imbalance became problematic, the state authority went about mediating this by maneuvering to compensate, for example the presence of the (Islamic) Diyanet in France alongside the funding favoritism to Catholic institutions. State violation of Laicism fosters political fragmentation, and consequently deepening exclusion, deepening imbalance. All of these factors lend themselves to politico-economic volatility, which in turn prompts desperation at the uppermost levels of government to control it. France favored majority Catholic demographics, while Turkey catered to its dominant Sunni population. In the long term, these national "secular" institutions provide a means for the state to exclude not religious groups, but minority religious, political, and ethnic groups. The parallel paths of France Turkey and diverge as France confronted an identity under threat, and Turkey attempted to confront economic crisis and a drought of qualified political candidates. The result, as we've witnessed recently, it that France tightened its arguably over-firm grip upon enforceable Laicism, while Turkey threw it overboard and drowned it in the Bosporus. Most notably, they each conducted back-door maneuver's regarding the role religion in state processes while adamantly proclaiming secularism. [2] While the reversal of Turkey from a secular to an openly Islamic administration disintegrated French and Turkish comparability as secular interventionist cases, the study of their divergence yields insights to democracy studies, religion in politics studies, and topics surrounding nationalism and political deconstruction.

\subsection{Research}

I began this research about 8 months prior to the wave of PKK terrorist bombings that began in early 2015. All through these security crises, it was unclear whether Turkey would capitalize on the economic opportunities that lay before it or if Erdoğan would capitalize on rising insecurity. Clearly, the pendulum has swung in favor of the latter. By the day, Turkey is rapidly transitioning into a milder form of Stalinist-styled State. In a sense, as its policy leans eastward the Turkish politic is increasingly resembling its new ally (Russia) rather than its former one (The United States). Moving forward, Turkey's reigning hope to rise above its current crisis rests not upon economic success (as it did as soon as recently as 2015), but potentially its collapse. In lieu of massive job loss, the $2.5-3$ million refugees unsustainably inhabiting in the country, instability generated by increasing threats from ISIL, and spillover from the Syrian crisis, AKP cannot alienate the bourgeoisie who support him. Formerly, AKP benefited from the demographics excluded by the reigning secularists, i.e. Islamists. Their inclusion of these groups and their insight not to interrupt the flow of capitalist profits created a group of staunchly loyal supporters who benefited from his leadership. Those who feel they owe their loyalty to AKP will not dissipate overnight as he dismantles the jobs he once created, but if prosperity thins, tensions rise, and the economy falls, support. With that said, the wounds created by the attempted coup of 2016 will take time to heal. Until that point, Erdoğan systematic reinstatement of Islam in formal politics carries with it an equal aggression with which religion was originally ousted.

The 'selective preference' of dominant religious agendas generated inequities that lent itself to exclusion and ultimately instability. Political and religious minorities are largely on the losing end of assertively Laic government institutions. In Turkey, these groups are largely represented 
by Alevis, Kurds, Women, as well as left and center (opposition) parties. In France, discrimination also circles the drain of religion, working against Muslim, Jewish, and Protestant populations particularly immigrants. In both contexts, marginalized immigrants and minority ethnic groups are further limited because of legislature enacted that staunchly enforce laic secularism (as by political vigilantes in France) or in disregard of the institutions that guard it (as in the rise of Islamist parties and economic coalitions in Turkey). In the name of national preservation, Laicism as a principle is corrupt in both the Turkish and French contexts: first instrumentalized and then overshadowed by the cause it has been mobilized to represent.

\section{Appendix}

\subsection{Case Study Selection}

To my knowledge there are four countries that have Laicism specifically written in their founding documents: the French republic (from 1880 to present), Turkey (as of 1923), Portugal (as of 1834), and the United States (1776). Of these, only two have undergone significantly aggressive periods that actively attempted to remove religion from government and public sphere activities (France and Turkey). Of these, one remains (France). While each experience peaks and lull in the politicization of Laicism, if we are to study Assertive Laicism as a comparative political value, then our 'universe' of case study options consists entirely of these two countries. My research would assess periods of parallel, deviation, and causational aspects that reinforced Turkish laicism alongside France as a baseline "control" case.

This project acknowledges France as a flawed standard, embedded with its own violations of the church-state distance required or true secularism. The assumption that France is perfectly laic is so taken for granted that it has become a methodological weakness prevalent in much of work produced by contemporary literature, particularly in light of the rising threat of terrorism associated with Islam. In fact, there are significant violations to Laicism in the French system, which I have sought to draw attention to throughout this comparative case study. Counter to expectation, drastic infractions to Laic principles occur even during times that Laicism is most politicized as a 'hot topic' in popular media outlets. Even so, it is internationally unanimous that France presents the 'cleanest' example of laic secularity. For this reason, it remains the 'base-line' case study in this research.

By reweaving this aspect into the framework of the French-Turkish comparative, it highlights the many ways in which a shared deviation from a 'true' separation of church and state has unraveled. Although it is widely recognized that Turkey is no longer Laic (and by extension that the rigid secularism it once enforced was flawed) there are fewer studies that identify discrepancies in the French application of Laicism of articles in similarity within the Turkish context. In effect, similar developments in the Jacobin and Young Turk movements respectively have ascended along a similar path, albeit with an inverse momentum which has driven their 'outcomes' to fall on squarely opposite end of the religious-secular spectrum. Today, France is the only remaining assertively secular nation in the world.

\subsection{Methodology \& Organization}

In the interest of producing a holistic analysis, this project will utilize both quantitative and qualitative methods from interdisciplinary fields such as political science, economics, and statistics. Using basic statistics to interpret the data provided by shifts in the distribution of parliamentary power, I have visualized these trends using the analytics program, "Minitab." All additional inferences are grounded in evidence published by international bodies such as the United Nations, European Commission, European Union, and others. Special care has been taken to confirm numbers presented by the French and Turkish governments themselves by confirmation with third party international sources. Qualitatively, the majority of this work interprets the nature and timing of legislature in conjunction with constitutional changes that may reflect Laicism's ebb and flow. Although, I prioritize primary source information whenever possible (legislature, constitutions, etc.), both primary and secondary historical sources, archival material, interviews where possible, and backed by media publications. I acknowledge the interpretive limits I may have given that, for the moment, I am limited to working with translations of the original Turkish documents. However, I can access to the 'organic versions' of the French and English documents. Additionally, significant considerations have been given to the author selection amongst my sources so that the equal proportions of French and Turkish authors are represented in my work.

The project is organized sequentially and in chronological order, beginning with France (as the baseline) and following with Turkey (as the subject of evaluation). I begin the project by establishing on three common denominators between Laicism's developments in each context and identify which time periods they are most comparable. This research focuses on laicism's founding in each case study (the early 19th century in France, and early 20th century in Turkey) and the decline of Laicism in Turkey (latter 20th century). The degree of politicization (dependent variable) was dependent upon the degree of mobilization (independent variable) in each case study as the state increased controls of Laicism through the 20th century. The project concludes with a final assessment of where the two countries left off after their respective 2007 
elections, and briefly review significant contemporary events, such as the Turkish coup or the new wave of legislature passed in France in 2016 in order to assess Laicism continued role in contemporary church-state tensions in both Turkey and France.

\section{REFERENCES}

[1] Gunn, T. Jeremy. 2004. "Under God but Not the Scarf: The Founding Myths of Religious Freedom in the United States and Laïcité in France". Journal of Church and State 46 (1). Oxford University Press: 7-24.

http://www.jstor.org/stable/23920642.

[2] Kuru, Ahmet T. 2007. "Passive and Assertive Secularism: Historical Conditions, Ideological Struggles, and State Policies toward Religion”. World Politics 59 (4). Cambridge University Press: 568-94.

http://www.jstor.org/stable/40060173.

[3] Parla, Taha; Davison, Andrew. Rethinking Kemalism's 'Six Arrows.' Corporatism in Kemalist Turkey.

[4] Gunn, Jeremy. Interview by Julia Jakus. Informal. International University of Rabat. 28 March, 2016.

[5] Keyman, E. Fuat, and Berrin Koyuncu. 2005. "Globalization, Alternative Modernities and the Political Economy of Turkey". Review of International Political Economy 12 (1). Taylor \& Francis, Ltd.: 105-28.

http://www.jstor.org/stable/25124010.

[6] Translation by author.

[7] Daventry, Michael Sercan. "Turkish Political Road Map,"JamesInTurkey.com:

http://www.jamesinturkey.com/roundups/turkish-political-roa d-map/\#comment-266894

[8] Green, Penny. 2005. "Disaster by Design: Corruption, Construction and Catastrophe". The British Journal of Criminology 45 (4). Oxford University Press 2005: 528-46. http://www.jstor.org/stable/23639253.

[9] Midgdalovitz, Carol. "Turkey's 2007 Elections: Crisis of Identity and Power" in CRS Report for Congress (Last updated 11 July 2007):

https://www.fas.org/sgp/crs/mideast/RL34039.pdf .

[10] Kuru, Ahmet T. 2008. "Secularism, State Policies, and Muslims in Europe: Analyzing French Exceptionalism". Comparative Politics 41 (1). Comparative Politics, Ph.D. Programs in Political Science, City University of New York: 1-19. doi:10.2307/20434102.

[11] Gunn, T. Jeremy. "Religious Freedom and Laïcité: A Comparison of the United States and France," Brigham Young University Law Review, 24 (Summer 2004), 435-36.

[12] Akan, Murat, "Twin Tolerations or Siamese Twins?: Kemalist Laicism and Political Islam in Turkey," in Institutions and Democracy: Essays in Honor of Alfred Stepan edited by Douglas Chalmers and Scott Mainwaring, University of Notre Dame Press (forthcoming, 2012)

[13] Okyar, Osman. 1965. "The Concept of Étatism". The
Economic Journal 75 (297). [Royal Economic Society, Wiley]: 98-111. doi:10.2307/2229238.

[14] Parla, Taha; Davison, Andrew. 2004. Corporatist ideology in Kemalist Turkey: Progress of Order? Syracuse University Press.

[15] Cemal Karakas, Turkey: Islam and Laicism Between the Interests of State, Politics, and Society, Peace Research Institute of Frankfurt (PRIF) Reports No. 78, (2007), pp. 25.

[16] Willis, Michael J. ,Chapter 3 "Islamic Movements" in Politics and Power in the Maghreb from Independence to the Arab Spring, Hurst \& Co, (2012).

[17] Baubérot, Jean. 2008. "La Commission Stasi: Entre Laïcité Républicaine Et Multiculturelle". Historical Reflections / Réflexions Historiques 34 (3). Berghahn Books: 7-20. http://www.jstor.org/stable/23235177.

[18] Perego, Elizabeth. The veil or a brother's life: French manipulations of Muslim women's images during the Algerian War, 1954-62. (Journal of North African Studies, 20/3, pp. 356.

[19] Kettani, M. Ali. 1997. "Post-Ottoman Islamic Educational Institutions in the Balkans." Islamic Studies 36 (2/3). Islamic Research Institute, International Islamic University, Islamabad: 465-76. http://www.jstor.org/stable/23076207.

[20] Akan, Murat. "The Infrastructural Politics of Laiklik in the Writing of the 1961 Turkish Constitution," Interventions: International Journal of Postcolonial Studies, 13:2 (2011).

[21] EC Europa. (File: First time asylum applicants by citizenship, EU-28, relative change between Q4 2014 and Q5 2015. png) http://ec.europa.eu/eurostat/statistics-explained/index.php/Fil e:First time_asylum_applicants_by_citizenship,_EU-28,_rela tive_change_between_Q4_2014_and_Q4_2015.png).

[22] Eurostat. Tables 1 Asylum Quarterly Report in Eurostat Statistics Explained.

http://ec.europa.eu/eurostat/statistics-explained/index.php/As ylum quarterly report .

[23] European Community Report, Economic Papers 386, Growth and Economic Crisis in Turkey: Leaving behind a Turbulent Past, October 2009,

http://ec.europa.eu/economy_finance/publications/publication 16004 en.pdf, pp. 5.

[24] "French National Assembly Adopts Immigration Bill," Global Legal Monitor, Library of Congress. (Published 9 September 2015):

http://www.loc.gov/law/foreign-news/article/france-nationalassembly-adopts-immigration-bill/.

[25] Martone, Eric 2009. "In the Shadow of Rousseau: Gender and the 2007 French Presidential Elections." International Social Science Review 84 (1/2). Pi Gamma Mu, International Honor Society in Social Sciences: 3-25.

http://www.jstor.org/stable/41887387.

[26] Larkin, Mauric. Church and State after the Dreyfus Affair: The Separation Issue in France (New York: Barnes \& Noble, 1973), pp. 70-79.

[27] EurActive: EU New and Policy Debates, TÜSIAD: Cyprus Issue Should Not Harm Turkey's EU Membership Process.

[28] Wilkens, Katherine A. 1998. “Turkey: Emerging Regional 
Power or State in Crisis?". Great Decisions. Foreign Policy Association, 75-85. http://www.jstor.org/stable/43682416.

[29] Öniş, Ziya, and Umut Türem. 2002. "Entrepreneurs, Democracy, and Citizenship in Turkey". Comparative Politics 34 (4). Comparative Politics, Ph.D. Programs in Political Science, City University of New York: 439-56. doi: $10.2307 / 4146947$.

[30] Stepan, Alfred C. The World's Religious Systems and Democracy: Crafting the "Twin Tolerations." Religious Systems and Democracy. (Chpt. 11, pp. 212-253).

[31] Topal, Semiha. 2012. "Everybody Wants Secularism-but Which One? Contesting Definitions of Secularism in Contemporary Turkey". International Journal of Politics, Culture, and Society 25 (1/3). Springer: 1-14. http://www.jstor.org/stable/23279941.

[32] Armstrong, William. "The Mobilization of Turkish Islamism," Hurriet Daily News: (Last viewed on 19 June 2016): http://www.hurriyetdailynews.com/the-mobilization-of-turkis h-islamism.aspx?pageID $=238 \& n I D=64129 \&$ NewsCatID $=47$ 4.

[33] Cornell, Svante. "The Rise of Diyanet: the Politicization of Turkey's Directorate of Religious Affairs" in The Turkey Analyst:

http://www.turkeyanalyst.org/publications/turkey-analyst-arti cles/item/463-the-rise-of-diyanet-the-politicization-of-turkey' s-directorate-of-religious-affairs.html.

[34] Hooper, Ben. "Turkish Religious Body: Toilet Paper Allowed by Islam." UPI. (published 7 April 2015):
http://www.upi.com/Odd News/2015/04/07/Turkish-religiou s-body-Toilet-paper-allowed-by-Islam/8351428423648/ .

[35] "Prof. Dr. Mehmet Görmez: Papa'nın Açıklaması Ahlak Diș1", TRT Diyanet, (published: 24 April 2015): http://www.diyanet.tv/prof-dr-mehmet-gormez-papanin-acikl amasi-ahlak-disi/

[36] Akan, Murat. "Turkey's Attempt at a New Constitution in Political Context," Anyasa Hukuku Dergisi (Journal of Constitutional Law) 3:6 (2014).

[37] Akan, Murat. POLS_404.01 Lecture Notes. Boğaziçi University, Professor Murat Akan. 28 April- 18 May 2015.

[38] Article 136 of the Turkish Constitution.

[39] Çamlıbel, Cansu. "Early Elections Not Supported by Turkey Top Business Body." Hurried Daily News. (published 22 June 2015):

http://www.hurriyetdailynews.com/early-elections-not-suppor ted-by-turkeys-top-business-body-.aspx? pageID $=238 \& n I D=8$ 4305\&NewsCatID $=338$.

[40] Farrell, Heather. "French Presidential Elections." Washington Post. (13 April 2007): http://www.washingtonpost.com/wp-dyn/content/article/2007 /04/13/AR2007041301401.html .

[41] POLS 404.01 Class Notes. Boğaziçi University, Professor Murat Akan. 28 April- 18 May 2015.

[42] Figure 1. "Methods of Difference and Similarity: U.S., France, and Turkey." Kuru, Ahmet T. (2007). 